[Regular Paper]

\title{
Sulfur-tolerance of $\mathrm{Al}_{2} \mathrm{O}_{3}$ - and $\mathrm{TiO}_{2}$-supported Bimetallic Pt-Pd Catalysts for Naphthalene Hydrogenation
}

\author{
Koki Ito, Kaori Satoh, Tadahiro Tomino, Masao MiyaKe, Masa-aki Ohshima, \\ Hideki Kurokawa, Kazuo SugiYama, and Hiroshi Miura*
}

Dept. of Applied Chemistry, Faculty of Engineering, Saitama University, Shimo-Okubo 255, Sakura-ku, Saitama 338-8570, JAPAN

(Received February 27, 2003)

\begin{abstract}
Naphthalene hydrogenation was carried out over $\mathrm{TiO}_{2}$ - and $\mathrm{Al}_{2} \mathrm{O}_{3}$-supported bimetallic Pt-Pd catalysts at 0.95 $2.45 \mathrm{MPa}$ and $473 \mathrm{~K}$ with and without addition of dimethyldisulfide. The bimetallic catalysts were characterized by infrared spectroscopy of the adsorbed CO. Compared with the Pt-supported catalysts, the Pd-supported catalysts had higher catalytic activity in the presence of sulfur. Pd catalysts had a higher sulfur-tolerance, because the catalytic activity of the Pt catalysts was higher than that of the Pd catalysts in the absence of sulfur. Coexistence of Pd with Pt induced significant synergy in the catalytic properties in the presence of sulfur. However, such synergy was not observed in the absence of sulfur. The optimum $\mathrm{Pd} /(\mathrm{Pt}+\mathrm{Pd})$ molar ratio for the $\mathrm{Al}_{2} \mathrm{O}_{3}$ - and $\mathrm{TiO}_{2}$-supported catalysts was 0.8 and 0.5 , respectively. The difference was an effect of metal particle size. Infrared spectroscopy of the adsorbed $\mathrm{CO}$ on the bimetallic catalysts showed the formation of Pt-Pd bimetallic particles. However, no electronic interaction between Pt and Pd was observed. Therefore, the synergy was due to the geometric effect.
\end{abstract}

\section{Keywords}

Naphthalene hydrogenation, Bimetallic catalyst, Platinum-palladium catalyst, Titanium oxide support, Aluminum oxide support, Sulfur tolerance

\section{1. 緒言}

軽油燃料由来の黒煙，パティキュレート（PM: Particulate matter）の排出削減が求められている1)。これらの有害物質の 生成は軽油中の芳香族炭化水素に起因することから，水素化処 理により飽和の炭化水素に転化するプロセスが提案されてい る2) 6)。一般に, 水素化反応が発熱反応であることから, 高温, 高水素分圧条件下では熱力学的平衡の制約を受ける2),3)。その ため，プロセスを稼動させるには，低温で高い水素化能を有す る触媒が必須であり，担持貴金属触媒に注目が集まっている。 しかし，担持貴金属触媒は軽油中に存在する硫黄成分により被 毒を受ける。このような背景を受け，耐硫黄性を示す担持貴金 属触媒の開発が盛んに行われている(1) 6)。それらの報告による と, $\mathrm{Pt}$ と $\mathrm{Pd}$ の複合化は硫黄成分存在下での触媒活性を大幅に 向上させる。このような, 貴金属成分の複合化による触媒活性 の向上は，しばしば貴金属間での電子的な相互作用による電子 久損金属種の生成に帰属されている6。電子密度の低い金属は, 硫黄（貴金属に対し電子受容体として働く）との結合が弱いた め, 反応中に活性サイトである金属表面が露出しやすいことに 起因する。しかしながら, Pawelec ら ${ }^{4)}$ は, そのような電子的 相互作用の可能性を, XPS (X-ray photoelectron spectroscopy) 分析および触媒上に吸着した CO の赤外吸収スペクトルにより

* To whom correspondence should be addressed.

* E-mail: hmiura@apc.saitama-u.ac.jp
否定している。このように, Pt と Pd の複合化による活性向上 因子については，いまだ不明な点が多い。

そこで本研究では, 硫黄化合物存在下での $\mathrm{Al}_{2} \mathrm{O}_{3}, \mathrm{TiO}_{2}$ 担持 Pt-Pdバイメタリック触媒によるナフタレン水素化反応を行 い, Pt と Pdの複合効果について検討した。さらに, COをプ ローブとした赤外吸収スペクトルにより, その活性向上因子に ついて調査を行った。

\section{2. 実験}

\section{1. 触媒調製}

担持金属触媒は含浸法もしくは共含浸法により調製した。金 属原料には，それぞれ $\mathrm{PdCl}_{2}$ (関東化学 (株) 製), $\mathrm{H}_{2} \mathrm{PtCl}_{6}$ (関 東化学(株)製）を用いた。 $\mathrm{TiO}_{2}$ (日本アエロジル(株)製，P-25） もしくは $\mathrm{Al}_{2} \mathrm{O}_{3}$ (水澤化学工業(株) 製, Neobead-GB) に金属成 分を担持後, $403 \mathrm{~K}$ で一昼夜乾燥させた。続いて $773 \mathrm{~K}$ で 3 時 間空気流通下焼成, $673 \mathrm{~K}$ で 5 時間水素還元を行った。総金属 担持量は $2 \mathrm{wt} \%$ とした。

\subsection{CO の化学吸着量の測定}

$\mathrm{CO}$ 化学吸着量はパルス式吸着法により測定した。触媒の前 処理は, $403 \mathrm{~K} て ゙ ~ 0.5$ 時間真空排気の後, $673 \mathrm{~K}$ で 1 時間水素 還元を行った。その後, 同温にて 1 時間, 真空排気を行った。 CO の定量は TCD（thermal conductivity detector）ガスクロマト グラフ (カラム: Active carbon) を用いた。測定した CO 化学 吸着量を基に, $\mathrm{CO} /$ 表面露出金属 $=1$ を仮定し, 触媒中の表 


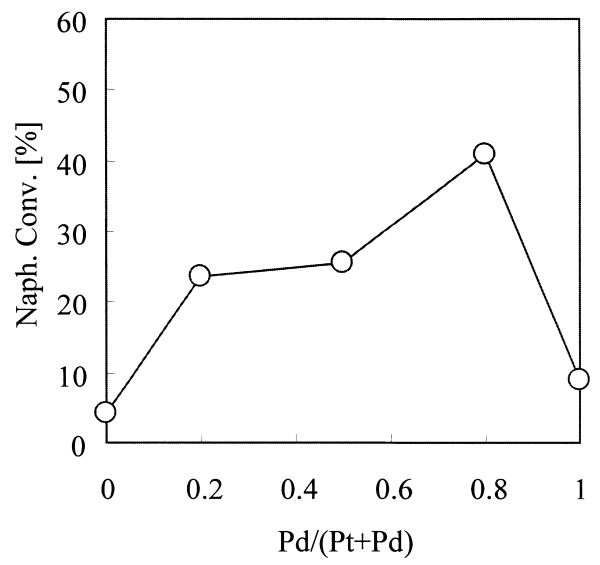

Reaction conditions:

Reaction temp. $473 \mathrm{~K}$, initial $\mathrm{H}_{2}$ pressure $0.95 \mathrm{MPa}$, feed (naphthalene)/solvent(tridecane) $0.195 \mathrm{~mol} / l$, reaction time 2 $\mathrm{h}$, catalysts weight $0.1 \mathrm{~g}$.

Fig. 1 Naphthalene Hydrogenation over Bimetallic Pt-Pd/ $\mathrm{Al}_{2} \mathrm{O}_{3}$ Catalysts without Addition of DMDS

\section{面金属数を算出した。}

\section{3. 活性試験}

ナフタレン水素化反応は，ステンレス製バッチ式高圧反応装 置（オートクレーブ）を用い，反応温度 $473 \mathrm{~K}$ ，初期水素圧 0.95 2.45 MPa で行った。原料のナフタレン（Merck 社製，べ ンゾチオフェンとして $380 \mathrm{wt}-\mathrm{ppm}$ の硫黄を含有する。ベンゾ チオフェン量は反応条件下では 10.6 wt-ppm に相当し，この量 は後に添加するジメチルジスルフィドに比べて十分に少ない量 である。）を，所定量のジメチルジスルフィドを含有した溶媒 のトリデカンに溶解させ反応溶液とした。触媒は, 反応前に $673 \mathrm{~K}$ で 1 時間，水素還元の後，空気に暴露させないように定 量的にオートクレーブに移送した。その後，オートクレーブ内 を水素で 3 回置換し，反応温度まで電気炉により昇温した。所 定の温度 $(473+10 \mathrm{~K})$ まで昇温した後，水素を充填し，かく はんを開始した。反応の停止は，かくはんを止め，オートクレ ーブを氷水に浸漬させることで行った。生成物の分析はFIDGC (hydrogen-flame ionization detector gas chromatography, カラ ム: DB-17， $30 \mathrm{~m} \times 0.25 \mathrm{~mm}$ ) により行った。

なお，各触媒の耐硫黄性の評価には，反応中に速やかに分解 し， $\mathrm{H}_{2} \mathrm{~S}$ を生成するジメチルジスルフィド（DMDS）を添加す る硫黄化合物として選択した。本化合物は，反応中に以下に示 す吸着平衡に速やかに達し，その吸着平衡が右辺によっている 触媒がより耐硫黄性に優れていると評価した。

$$
\text { S-Metal } \text { surface }_{\text {S }}+\mathrm{H}_{2} \Leftrightarrow \underset{\text { (Active site) }}{\text { Metal }_{\text {surface }}+\mathrm{H}_{2} \mathrm{~S}}
$$

\section{4. 触媒上に吸着した CO の赤外吸収スペクトル}

赤外吸収スペクトルは，自作の横型赤外セルにより行い，ス ペクトルの記録はフーリエ变換赤外分光器 Jasco FT/IR-350（日 本分光(株)製）を用いた。触媒は， $\phi 10 \mathrm{~mm}$ のディスクに成形 した後，赤外セル内で $673 \mathrm{~K}$ の水素還元を施した。続いて，同 温で真空排気 $\left(<10^{-4}\right.$ Torr, 1 Torr = 133.322 Pa) を施した。CO の吸着は，室温， $\mathrm{CO}$ 分圧: 20 Torr，0.5 時間の条件で行い，そ

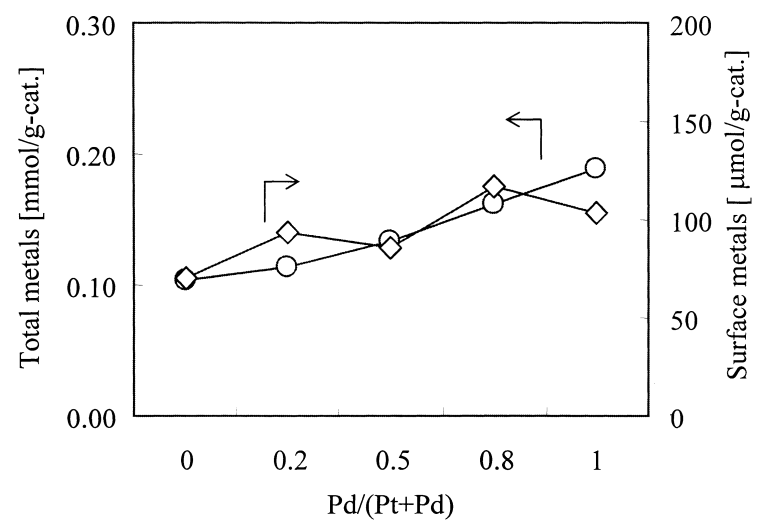

$\diamond$ Amount of surface metals, $\bigcirc$ Amount of total metals.

Fig. 2 Amount of Surface Metals of Bimetallic Pt-Pd/ $\mathrm{Al}_{2} \mathrm{O}_{3}$ Catalysts Determined by CO Chemisorption

の後，未吸着および物理吸着したCO を排気処理 $\left(<10^{-4}\right.$ Torr, 0.5 時間）により除去した。

スペクトルは, すべて分解能 $2 \mathrm{~cm}^{-1}$, 積算回数 128 回で行っ た。

\section{3. 結 果}

3. 1. $\mathrm{Al}_{2} \mathrm{O}_{3}$ 担持 Pt-Pd バイメタリック触媒によるナフタレ ン水素化反応

ナフタレン水素化反応は, 一つの芳香環が水素化されたテト ラヒドロナフタレンを経由し, さらにもう一つの芳香環が水素 化されたデカヒドロナフタレンを生成する逐次反応である。し かし, 本研究では速度論的解析のため, 反応条件を調節し, 生 成物はテトラヒドロナフタレンのみとした。

Fig. 1 に, $\mathrm{Pt}-\mathrm{Pd} / \mathrm{Al}_{2} \mathrm{O}_{3}$ 触媒によるジメチルジスルフィド （DMDS）を添加しない場合での触媒活性を示した。試験した モノメタリック触媒を比較すると, $\mathrm{Pt} / \mathrm{Al}_{2} \mathrm{O}_{3}$ 触媒より $\mathrm{Pd} / \mathrm{Al}_{2} \mathrm{O}_{3}$ 触媒が高活性であった。一方, $\mathrm{Pd} /(\mathrm{Pt}+\mathrm{Pd})$ モル比の異なるバ イメタリック触媒は, 担持 $\mathrm{Pt}$ 触媒もしくは担持 $\mathrm{Pd}$ 触媒よりも 高活性であり，Ptと Pdの複合効果を示した。特に Pt-Pd(Pd: $0.8) / \mathrm{Al}_{2} \mathrm{O}_{3}$ 触媒が大幅に高い触媒活性を示した。

Fig. 2 に, $\mathrm{Pt}-\mathrm{Pd} / \mathrm{Al}_{2} \mathrm{O}_{3}$ 触媒の $\mathrm{CO}$ 化学吸着量から見積もった 表面露出金属数を示した。3 種の $\mathrm{Pt}-\mathrm{Pd} / \mathrm{Al}_{2} \mathrm{O}_{3}$ 触媒の表面露出 金属数は，複合化により金属粒子の分散性に影響を与えなかっ た。したがって, 複合化による触媒活性の向上は, 水素化の活 性サイトである表面露出金属数の増加には起因しない。

Fig. 3 に，表面露出金属数を基に算出したターンオーバー頻 度 (Turnover Frequency; TOF) を示した。モノメタリック触媒 では, $\mathrm{Pt} / \mathrm{Al}_{2} \mathrm{O}_{3}$ 触媒より $\mathrm{Pd} / \mathrm{Al}_{2} \mathrm{O}_{3}$ 触媒が高活性であった。また, バイメタリック触媒では, それぞれのモノメタリック触媒より 高活性であり, 特に Pt-Pd(Pd: 0.8$) / \mathrm{Al}_{2} \mathrm{O}_{3}$ 触媒が最も高い TOF を示した。よって, 触媒活性の向上は活性点の質的向上に起因 することが明らかである。

Fig. 4 に，硫黄化合物として反応系に添加したDMDS が $\mathrm{Pt}-\mathrm{Pd} / \mathrm{Al}_{2} \mathrm{O}_{3}$ 触媒の触媒活性へ与える影響について示した。添 加した硫黄量は表面露出金属を十分に被覆する量である（ナフ 


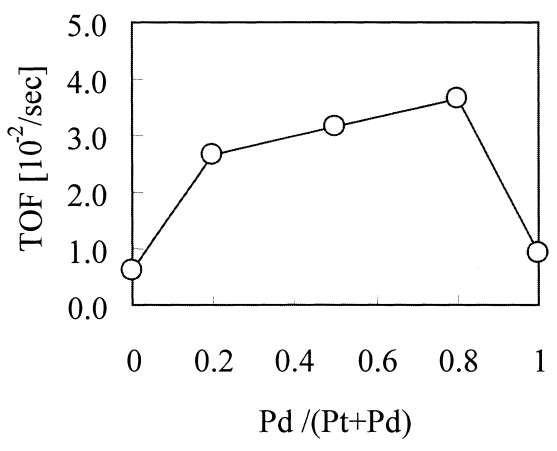

Reaction conditions:

Reaction temp. $473 \mathrm{~K}$, initial $\mathrm{H}_{2}$ pressure $0.95 \mathrm{MPa}$, feed (naphthalene)/solvent(tridecane) $0.195 \mathrm{~mol} / l$, reaction time 2 h, catalysts weight $0.1 \mathrm{~g}$.

Fig. 3 Turn over Frequency (TOF) of Naphthalene Hydrogenation over $\mathrm{Pt}-\mathrm{Pd} / \mathrm{Al}_{2} \mathrm{O}_{3}$ Catalysts without Addition of DMDS

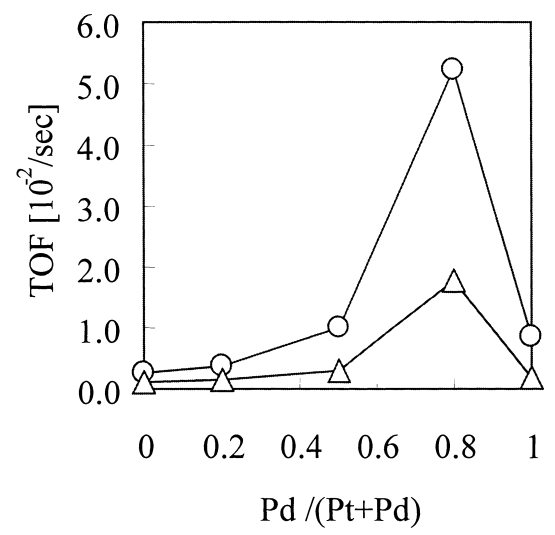

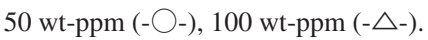

Reaction conditions:

Reaction temp. $473 \mathrm{~K}$, initial $\mathrm{H}_{2}$ pressure $2.45 \mathrm{MPa}$, feed (naphthalene)/solvent(tridecane) $0.195 \mathrm{~mol} / \mathrm{l}$.

Fig. 4 Effect of Pd Content on Catalytic Activity of Pt-Pd/ $\mathrm{Al}_{2} \mathrm{O}_{3}$ Catalysts for Naphthalene Hydrogenation

タレン原料由来の硫黄 (ベンゾチオフェン) 量は反応条件下で 10.6 wt-ppm であり, $0.2 \mathrm{~g}$ の $\mathrm{Pd} / \mathrm{Al}_{2} \mathrm{O}_{3}$ 触媒を使用の場合, 18.4 wt-ppm の硫黄で表面 Pdを被覆することが可能である)。 DMDS の添加は $\mathrm{Al}_{2} \mathrm{O}_{3}$ 担持触媒の活性を大幅に減少させた。 $\mathrm{Pt}-\mathrm{Pd}(\mathrm{Pd}: 0.8) / \mathrm{Al}_{2} \mathrm{O}_{3}$ は, 試験した触媒の中で最も高活性であり, 硫黄に対する耐性に優れていた。また，硫黄濃度によらず最適 $\mathrm{Pd} /(\mathrm{Pt}+\mathrm{Pd})$ モル比は変化しなかった。

\section{2. $\mathrm{TiO}_{2}$ 担持 Pt-Pd バイメタリック触媒によるナフタレ ン水素化反応}

Fig. 5 に，ジメチルジスルフィド（DMDS）を添加しない場 合の $\mathrm{Pt}-\mathrm{Pd} / \mathrm{TiO}_{2}$ 触媒の活性を示した。試験したモノメタリック 触媒を比較すると, $\mathrm{Al}_{2} \mathrm{O}_{3}$ 担持触媒と同様に, $\mathrm{Pt} / \mathrm{TiO}_{2}$ 触媒より $\mathrm{Pd} / \mathrm{TiO}_{2}$ 触媒が高活性であった。一方，バイメタリック触媒で は，Pt-Pd(Pd: 0.5)/ $/ \mathrm{TiO}_{2}$ が最も高活性であったが, $\mathrm{Pd} /(\mathrm{Pt}+\mathrm{Pd})$

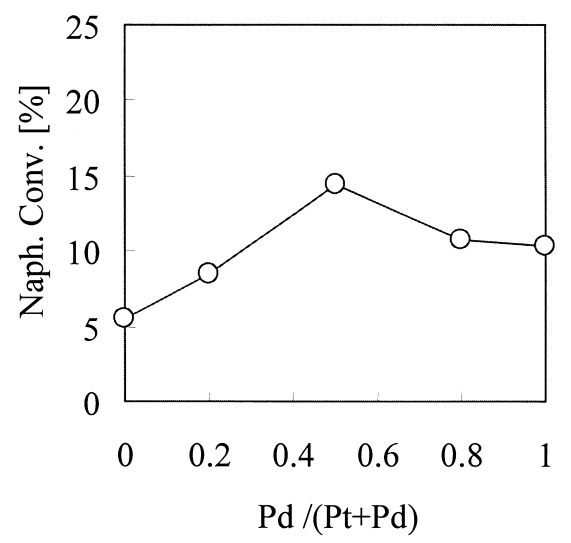

Reaction conditions:

Reaction temp. $473 \mathrm{~K}$, initial $\mathrm{H}_{2}$ pressure $0.95 \mathrm{MPa}$, feed (naphthalene)/solvent(tridecane) $0.195 \mathrm{~mol} / l$, reaction time 2 $\mathrm{h}$, catalysts weight $0.1 \mathrm{~g}$.

Fig. 5 Naphthalene Hydrogenation over Bimetallic Pt-Pd/ $\mathrm{TiO}_{2}$ Catalysts without Addition of DMDS

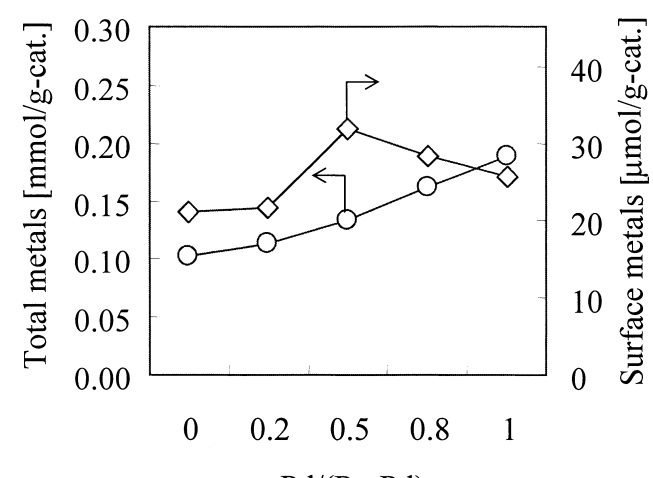

$\mathrm{Pd} /(\mathrm{Pt}+\mathrm{Pd})$

$\diamond$ Amount of surface metals, $\bigcirc$ Amount of total metals.

Fig. 6 Amount of Surface Metals of Bimetallic Pt-Pd/TiO Catalysts Determined by CO Chemisorption

が触媒活性に与える影響は $\mathrm{Al}_{2} \mathrm{O}_{3}$ 担持触媒より小さかった。つ まり, $\mathrm{TiO}_{2}$ 担体上より $\mathrm{Al}_{2} \mathrm{O}_{3}$ 担体上で, $\mathrm{Pt}$ と $\mathrm{Pd}$ の複合効果が より顕著に発現した。

Fig. 6 に，Pt- $\mathrm{Pd} / \mathrm{TiO}_{2}$ 触媒の $\mathrm{CO}$ 化学吸着量より見積もった 表面露出金属数を示した。最も高活性を示した $\mathrm{Pt}-\mathrm{Pd}(\mathrm{Pd}:$ $0.5) / \mathrm{TiO}_{2}$ の表面露出金属数は $\mathrm{Pt}, \mathrm{Pd}$ のそれぞれのモノメタリ ック触媒より明らかに多かった。つまり, $\mathrm{TiO}_{2}$ 担持 $\mathrm{Pt}-\mathrm{Pd}$ 触媒 の触媒活性の向上は水素化の活性サイト数の増加がその一因で ある。この傾向は, 前述の $\mathrm{Pt}-\mathrm{Pd} / \mathrm{Al}_{2} \mathrm{O}_{3}$ 触媒の場合とは異なっ ている。これは, $\mathrm{Al}_{2} \mathrm{O}_{3}$ 担体上では貴金属が既に高分散化して いることから，このような Pt と Pd の複合効果は発現し難いた めと推察される。

Fig. 7 に, 表面露出金属数を基に算出したターンオーバー頻 度 $(T O F)$ を示した。モノメタリック触媒を比較すると, Pt/ $\mathrm{TiO}_{2}$ 触媒より $\mathrm{Pd} / \mathrm{TiO}_{2}$ 触媒が高活性であった。また, $\mathrm{Pt}-\mathrm{Pd}(\mathrm{Pd}:$ 


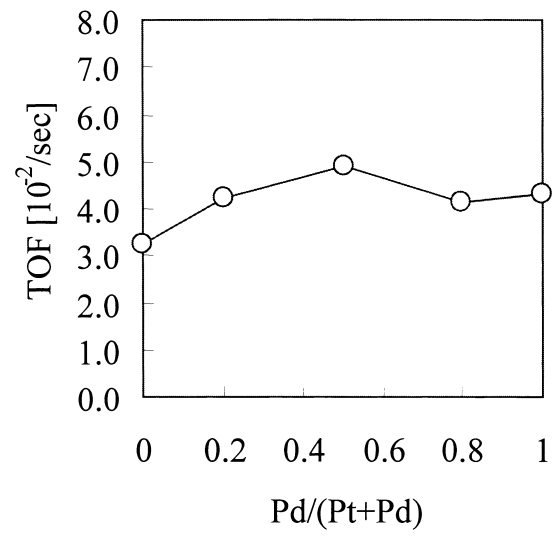

Reaction conditions:

Reaction temp. $473 \mathrm{~K}$, initial $\mathrm{H}_{2}$ pressure $0.95 \mathrm{MPa}$, feed (naphthalene)/solvent(tridecane) $0.195 \mathrm{~mol} / \mathrm{l}$, reaction time 2 $\mathrm{h}$, catalysts weight $0.1 \mathrm{~g}$.

Fig. 7 Turn over Frequency (TOF) of Naphthalene Hydrogenation over $\mathrm{Pt}-\mathrm{Pd} / \mathrm{TiO}_{2}$ Catalysts without Addition of DMDS

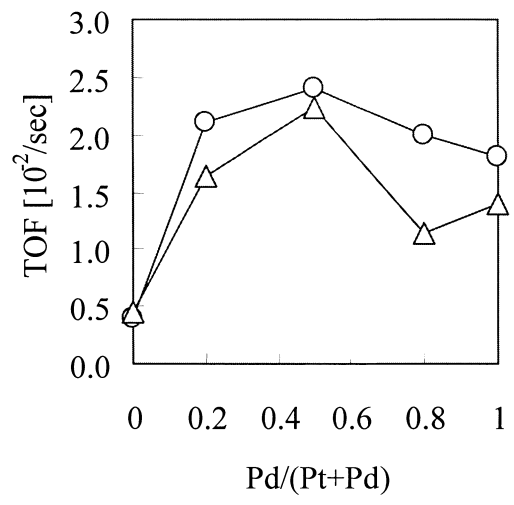

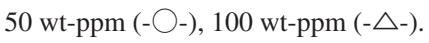

Reaction conditions:

Reaction temp. $473 \mathrm{~K}$, initial $\mathrm{H}_{2}$ pressure $2.45 \mathrm{MPa}$, feed (naphthalene)/solvent(tridecane) $0.195 \mathrm{~mol} / \mathrm{l}$.

Fig. 8 Effect of Pd Content on Catalytic Activity of Pt-Pd/ $\mathrm{TiO}_{2}$ Catalysts for Naphthalene Hydrogenation

0.5)/ $\mathrm{TiO}_{2}$ が最も高い TOF を示したものの, $\mathrm{Pt}-\mathrm{Pd} / \mathrm{Al}_{2} \mathrm{O}_{3}$ のよう な顕著な複合効果は示さなかった。これらの結果は, Pt-Pd/ $\mathrm{TiO}_{2}$ 触媒の触媒活性の向上は, 前述の活性サイト数の増加に 加え，活性点の質的向上を示している。

Fig. 8 に，硫黄化合物として反応系に添加したDMDSが $\mathrm{Pt}-\mathrm{Pd} / \mathrm{TiO}_{2}$ 触媒の触媒活性へ与える影響について示した。モノ メタリック触媒を比較すると, $\mathrm{Al}_{2} \mathrm{O}_{3}$ 担持触媒と同様に, $\mathrm{Pd}$ 触 媒が Pt 触媒よりも高かった。また, バイメタリック触媒では, モノメタリック触媒より TOF が高く, $\mathrm{Pt}-\mathrm{Pd}(\mathrm{Pd}: 0.5) \mathrm{TiO}_{2}$ 触媒 が最も高活性であった。さらに, 高い硫黄濃度では Pt と Pdの 複合効果が顕著に発現した。

以上の結果により，担体によらず Pd 触媒は Pt 触媒よりも高 活性であり, さらに $\mathrm{Pt}$ と $\mathrm{Pd}$ の複合化は大幅に触媒活性を向上
させることが分かった。また, $\mathrm{Al}_{2} \mathrm{O}_{3}$ 担持触媒では, その触媒 活性の向上は活性点の質的向上に起因し, $\mathrm{TiO}_{2}$ 担持触媒では 活性サイト数の増加および活性点の質的向上に起因することが 明らかとなった。このような $\mathrm{Pt}$ と $\mathrm{Pd}$ の複合効果は $\mathrm{TiO}_{2}$ 担体 上より $\mathrm{Al}_{2} \mathrm{O}_{3}$ 担体上で顕著に発現した。

\section{3. 触媒上に吸着した CO の赤外吸収スペクトル}

$\mathrm{Pt}$ と $\mathrm{Pd}$ の複合化により効果を発現させるには, 同一金属粒 子内に Pt と Pd がともに存在する必要がある。さらに, それら の成分間で電子的な相互作用が発現するには, それぞれの成分 が直接, 化学結合を形成しなければならない。そこで, 顕著な $\mathrm{Pt}$ と $\mathrm{Pd}$ の複合効果が発現した $\mathrm{Pt}-\mathrm{Pd} / \mathrm{Al}_{2} \mathrm{O}_{3}$ 触媒について, $\mathrm{CO}$ をプローブとして吸着させ，その赤外スペクトルにより金属粒 子表面の観察㧍よび Pt と Pdの相互作用について調査した。

Fig. 9 に, $\mathrm{Pt}-\mathrm{Pd} / \mathrm{Al}_{2} \mathrm{O}_{3}$ 上に吸着した $\mathrm{CO}$ の赤外スペクトルを 示す。なお, リファレンスとしてそれぞれモノメタリック触媒 での測定結果, および物理混合サンプルについての測定結果も 示した。物理混合サンプルについては, CO 化学吸着量より算 出された表面露出金属数を基に表面露出率がそれぞれのモル比 となるよう（バルクの組成のまま表面に露出したと仮定）に調 節した。

$\mathrm{P} / / \mathrm{Al}_{2} \mathrm{O}_{3}$ 触媒では, 直線型吸着種に帰属される $2075 \mathrm{~cm}^{-1}$ の 吸収帯が観測され, 架橋型吸着種に帰属される吸収帯はほとん ど観測されなかった。この結果は, Pt が高分散化されたこと を示し, $\mathrm{CO}$ 化学吸着量測定の結果と一致した。 $\mathrm{Pd} / \mathrm{Al}_{2} \mathrm{O}_{3}$ 触媒 では直線型, 架橋型吸着種がともに観測され, それぞれ数種の 吸着種からなる吸収帯であることがわかる。これまでに報告さ れている $\mathrm{Pd}$ 上に吸着した COの帰属は以下のと抢りであ る $^{7) ~}$ ： $2095 \mathrm{~cm}^{-1} \cdots$ 低配位数サイト（コーナー，エッジ）上の 直線型吸着種, $2080 \mathrm{~cm}^{-1} \cdots \operatorname{Pd}(100)$ 面上の直線型吸着種, $1983 \mathrm{~cm}^{-1} \cdots \operatorname{Pd}(100)$ 面上の架橋型吸着種, $1963 \mathrm{~cm}^{-1}$ および $1923 \mathrm{~cm}^{-1}$ は $\operatorname{Pd}(111)$ 面上の架橋型吸着種。さらに, 2135, $2162 \mathrm{~cm}^{-1}$ の吸収带は, $\mathrm{Al}_{2} \mathrm{O}_{3}$ 表面上のオクタヘドラル空孔で安 定化された $\mathrm{Pd}^{+}$および $\mathrm{Pd}^{2+}$ 上に吸着した $\mathrm{CO}$ にそれぞれ帰属さ れる ${ }^{10)}$ 。

一方, $\mathrm{Pt}-\mathrm{Pd} / \mathrm{Al}_{2} \mathrm{O}_{3}$ 触媒は直線型および架橋型吸着種がとも に観測され, 架橋型吸着種の吸収帯は $\mathrm{Pd} /(\mathrm{Pt}+\mathrm{Pd})$ モル比の変 化に伴い特徵的な挙動を示した。すなわち, $\mathrm{Pd} /(\mathrm{Pt}+\mathrm{Pd})$ モル 比の増加に伴い, それぞれ架橋型吸着種の吸収帯の強度は増加 したものの, $\mathrm{Pd} /(\mathrm{Pt}+\mathrm{Pd})$ モル比 $=0.8$ の触媒では, $\mathrm{Pd}(111)$ 面 上に架橋型で吸着した CO に帰属される $1960 \mathrm{~cm}^{-1}$ 付近の吸収 帯の強度が，物理混合サンプルと比較し，大幅に弱かった。 $\mathrm{Pt} / \mathrm{Al}_{2} \mathrm{O}_{3}$ 触媒では, 架橋型吸着種の $\mathrm{CO}$ がほとんど存在しない ことと合わせて考えると, Ptの幾何学的効果により金属粒子 表面での架橋型吸着種の形成が抑制されたためと考えられる。 これらの結果は, $\mathrm{Pt}-\mathrm{Pd} / \mathrm{Al}_{2} \mathrm{O}_{3}$ 触媒で Pt-Pd 結合が形成されたこ とを示している。

Figs. 10 および 11 には, 直線型吸着種の赤外吸収領域 （2000～2200 $\mathrm{cm}^{-1}$ ) に扔いて波形分離を行った結果を示した。 さらに波形分離された各吸収带の波数を Table 1 にまとめた。 $\mathrm{Pt} / \mathrm{Al}_{2} \mathrm{O}_{3}$ および $\mathrm{Pd} / \mathrm{Al}_{2} \mathrm{O}_{3}$ 触媒の赤外吸収スペクトルは, それぞ れ三および四つの吸収带に波形分離可能であった。また, Pt-Pd(Pd: 0.8) $/ \mathrm{Al}_{2} \mathrm{O}_{3}$ 触媒では五つの吸収帯に波形分離可能であ 

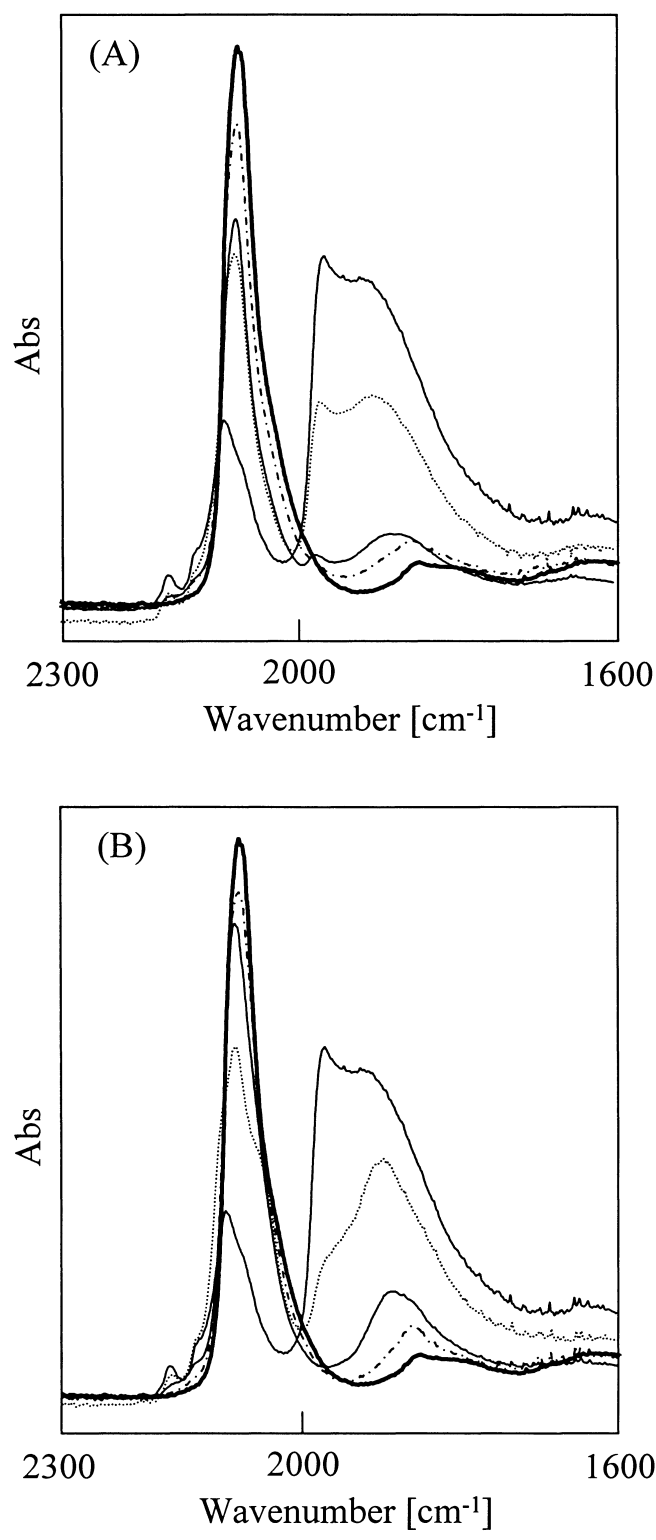

(A) Physical mixture of $\mathrm{Pt} / \mathrm{Al}_{2} \mathrm{O}_{3}$ and $\mathrm{Pd} / \mathrm{Al}_{2} \mathrm{O}_{3}$.

(B) Bimetallic $\mathrm{Pt}-\mathrm{Pd} / \mathrm{Al}_{2} \mathrm{O}_{3}$ prepared by co-impregnation method. $-\mathrm{Pd} / \mathrm{Al}_{2} \mathrm{O}_{3},-\cdots-\mathrm{Pt}-\mathrm{Pd}(\mathrm{Pd}: 0.2) / \mathrm{Al}_{2} \mathrm{O}_{3},-\mathrm{Pt}-\mathrm{Pd}(\mathrm{Pd}$ : 0.5) $/ \mathrm{Al}_{2} \mathrm{O}_{3}, \cdots \cdots \cdots . . . \mathrm{Pt}-\mathrm{Pd}(\mathrm{Pd}: 0.8) / \mathrm{Al}_{2} \mathrm{O}_{3},-\mathrm{Pt} / \mathrm{Al}_{2} \mathrm{O}_{3}$.

Fig. 9 Infrared Spectra of Adsorbed $\mathrm{CO}$ on Bimetallic Pt-Pd/ $\mathrm{Al}_{2} \mathrm{O}_{3}$ Catalyst

った。 $\mathrm{Pt}-\mathrm{Pd}(\mathrm{Pd}: 0.8) / \mathrm{Al}_{2} \mathrm{O}_{3}$ 触媒の各吸収帯の帰属は, $\mathrm{CO}$ が $\mathrm{Pt}$ と Pd ともに吸着することから困難であるが， $2051 \mathrm{~cm}^{-1}$ の吸収 帯は $\mathrm{Pd} / \mathrm{Al}_{2} \mathrm{O}_{3}$ 触媒では見られないことょり, $\mathrm{Pt}$ 上に吸着した $\mathrm{CO}$ に帰属される。さらに，その波数は， $\mathrm{Pt} / \mathrm{Al}_{2} \mathrm{O}_{3}$ 触媒の 2052 $\mathrm{cm}^{-1}$ とほぼ同様であり, Pt と Pd 間での電子的相互作用は存在 しないことを示している。

\section{4. 考察}

4. 1. $\mathrm{TiO}_{2}$ および $\mathrm{Al}_{2} \mathrm{O}_{3}$ 担持触媒の比較

Pt 触媒と Pd 触媒を比較すると，担体によらず Pd 触媒が触
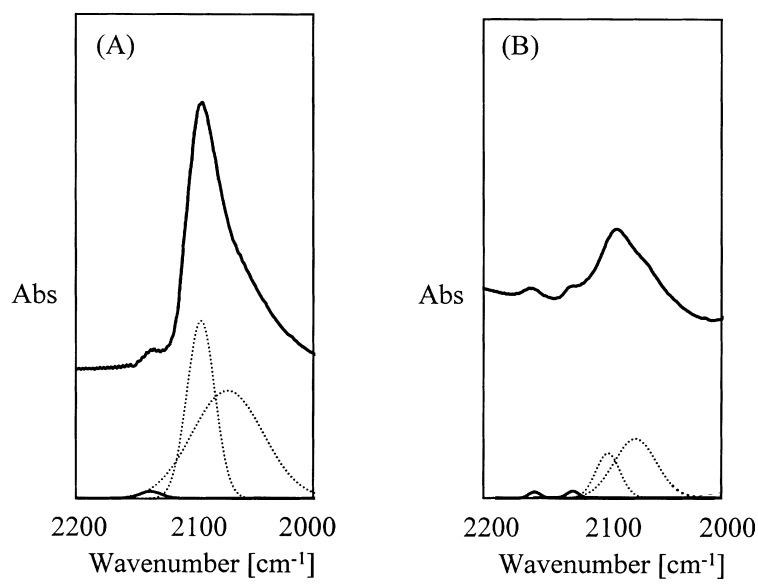

(A) $\mathrm{Pt} / \mathrm{Al}_{2} \mathrm{O}_{3}$, (B) $\mathrm{Pd} / \mathrm{Al}_{2} \mathrm{O}_{3}$.

Fig. 10 Infrared Spectra of CO Linearly Adsorbed on $\mathrm{Pt} / \mathrm{Al}_{2} \mathrm{O}_{3}$ and $\mathrm{Pd} / \mathrm{Al}_{2} \mathrm{O}_{3}$ in the Range of 2000 to $2200 \mathrm{~cm}^{-1}$

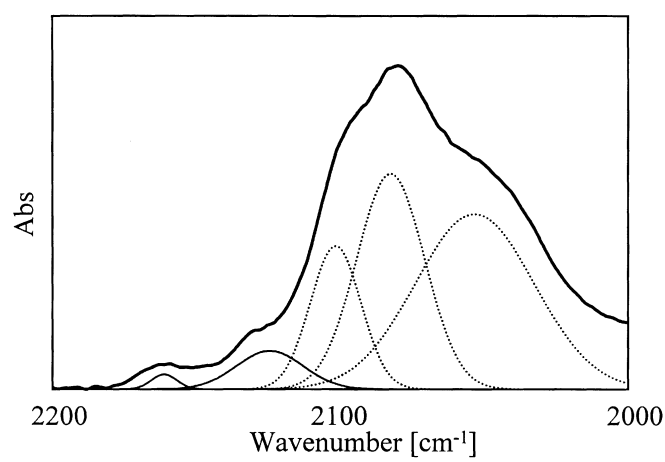

Fig. 11 Infrared Spectra of CO Linearly Adsorbed on Pt-Pd (Pd: 0.8) $/ \mathrm{Al}_{2} \mathrm{O}_{3}$ in the Range of 2000 to $2200 \mathrm{~cm}^{-1}$

Table 1 Infrared Spectroscopic Characteristics of Linearly Adsorbed CO Species on $\mathrm{Al}_{2} \mathrm{O}_{3}$-supported Catalysts (2000 to $2200 \mathrm{~cm}^{-1}$ )

\begin{tabular}{lc}
\hline \multicolumn{1}{c}{ Catalyst } & Peak $\left[\mathrm{cm}^{-1}\right]$ \\
\hline $\mathrm{Pt} / \mathrm{Al}_{2} \mathrm{O}_{3}$ & 2127 \\
& 2079 \\
& 2052 \\
$\mathrm{Pd} / \mathrm{Al}_{2} \mathrm{O}_{3}$ & 2162 \\
& 2135 \\
& 2095 \\
$\mathrm{Pt}-\mathrm{Pd}(\mathrm{Pd}: 0.8) / \mathrm{Al}_{2} \mathrm{O}_{3}$ & 1983 \\
& 2162 \\
& 2126 \\
& 2101 \\
& 2081 \\
& 2051 \\
\hline
\end{tabular}

媒活性，TOF ともに高かった。しかしながら， Table 2 に示す ように，原料ナフタレンに含有するベンゾチオフェンを脱硫操 作により除去する（<2 wt-ppm）と, Pt 触媒が Pd 触媒よりも 
Table 2 Effect of Feed Refining on Catalytic Activity for Naphthalene Hydrogenation

\begin{tabular}{|c|c|c|c|c|c|c|}
\hline \multirow[b]{2}{*}{ Catalyst } & \multicolumn{2}{|c|}{ Feed (naphthalene) } & \multirow[b]{2}{*}{$\begin{array}{l}\text { Reaction temp. } \\
\qquad \mathrm{K}]\end{array}$} & \multirow[b]{2}{*}{$\begin{array}{c}\text { Reaction time } \\
{[\mathrm{h}]}\end{array}$} & \multirow[b]{2}{*}{$\begin{array}{l}\text { Naph. conv. } \\
{[\%]}\end{array}$} & \multirow[b]{2}{*}{$\begin{array}{c}\text { TOF } \\
{\left[10^{-2} / \mathrm{sec}\right]}\end{array}$} \\
\hline & Desulfidation & $\begin{array}{l}\text { Sulfur concentration } \\
\text { [wt-ppm] }\end{array}$ & & & & \\
\hline \multirow[t]{2}{*}{$\mathrm{Pd} / \mathrm{Al}_{2} \mathrm{O}_{3}$} & No & $10^{2)}$ & 473 & 2 & 8.9 & 0.91 \\
\hline & Yes & $<2^{2)}$ & 323 & 1 & 13.0 & 2.90 \\
\hline \multirow[t]{2}{*}{$\mathrm{Pt} / \mathrm{Al}_{2} \mathrm{O}_{3}$} & No & $10^{2)}$ & 473 & 2 & 4.2 & 0.62 \\
\hline & Yes & $<2^{2)}$ & 323 & 1 & 27.1 & 8.3 \\
\hline
\end{tabular}

Reaction conditions; initial $\mathrm{H}_{2}$ pressure $=0.95 \mathrm{MPa}$ reactant, (naphthalene) $/$ solvent (tridecane) $=1 \mathrm{~g} / 40 \mathrm{ml}(0.195 \mathrm{~mol} / l)$.

1) $\mathrm{TOF}=$ turn over frequency.

2) Sulfur as benzothiophene determined by FID-GC.

触媒活性，TOF ともに大幅に向上する。同様な Pt 触媒の優位

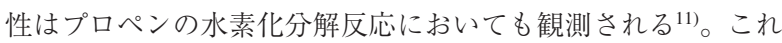
らの結果は, Pd 触媒はPt 触媒よりも耐硫黄性に優れているこ とを示している。

$\mathrm{TiO}_{2}$ 担持触媒と $\mathrm{Al}_{2} \mathrm{O}_{3}$ 担持触媒を比較すると, $\mathrm{Pt}, \mathrm{Pd}$ とも に $\mathrm{TiO}_{2}$ 担持触媒が $\mathrm{Al}_{2} \mathrm{O}_{3}$ 担持触媒よりも高い $T O F$ を示した。 さらに，金属を Pd に固定し，担体の種類による硫黄濃度の影 響 $(T O F(50 \mathrm{wt}-\mathrm{ppm}) / T O F(100 \mathrm{wt}-\mathrm{ppm}))$ を見積もると，それ ぞれ $\mathrm{Pd} / \mathrm{TiO}_{2}$ 触媒で $1.2, \mathrm{Pd} / \mathrm{Al}_{2} \mathrm{O}_{3}$ 触媒で 4.3 であり, $\mathrm{TiO}_{2}$ 担 持触媒が $\mathrm{Al}_{2} \mathrm{O}_{3}$ 担持触媒よりも硫黄の影響を受け難く, 耐硫黄 性が高いことが明らかである。

$\mathrm{TiO}_{2}$ 抒よび $\mathrm{Al}_{2} \mathrm{O}_{3}$ 担持 $\mathrm{Pt}-\mathrm{Pd}$ バイメタリック触媒では, Pt $\operatorname{Pd}$ の複合化により，両担体上でともに大幅な触媒活性の向上 が見られ, $\mathrm{TiO}_{2}$ 担持触媒と比較して $\mathrm{Al}_{2} \mathrm{O}_{3}$ 担持触媒で複合効果 がより大きかった。さらに, $\mathrm{Al}_{2} \mathrm{O}_{3}$ 担体上での最適 $\mathrm{Pd} /(\mathrm{Pt}+\mathrm{Pd})$ モル比は 0.8 であり, $\mathrm{TiO}_{2}$ 担持触媒では 0.5 であった。Yasuda ら5) は, $\mathrm{Pt}-\mathrm{Pd} / \mathrm{USY}$ 触媒では最適 $\mathrm{Pd} /(\mathrm{Pt}+\mathrm{Pd})$ モル比を 0.8 と報 告して抢り, 同様の結果は $\mathrm{B}_{2} \mathrm{O}_{3}-\mathrm{Al}_{2} \mathrm{O}_{3}{ }^{2)}, \mathrm{SiO}_{2}-\mathrm{Al}_{2} \mathrm{O}_{3}{ }^{3)}$ 等の酸 性酸化物担持触媒でも得られる。これらの報告では, いずれも 最適 $\mathrm{Pd} /(\mathrm{Pt}+\mathrm{Pd})$ モル比は 0.8 付近であり, 本研究で得られた $\mathrm{TiO}_{2}$ 担持触媒の 0.5 とは異なる。ところで, $\mathrm{Pt}$ と $\mathrm{Pd}$ のバイメ タリック粒子の表面組成については, 表面分析や計算化学的シ ミュレーションにより種々の検討が行われている。Rousset ら ${ }^{12)}$ は，モンテカルロ法による計算化学的アプローチにより, Pt-Pd バイメタリック粒子では Pdの表面偏析が起こることを 報告している。その報告によれば，総原子数 586 の金属粒子で $\mathrm{Pd} /(\mathrm{Pt}+\mathrm{Pd})$ モル比 $=0.15$ の粒子の場合, 表面の $26.8 \%$ が $\mathrm{Pd}$ で 覆われ, $\mathrm{Pd} /(\mathrm{Pt}+\mathrm{Pd})$ モル比 $=0.5$ の粒子で $73.9 \%$ が $\mathrm{Pd}$ で覆わ れる。さらに, 総原子数 2406 の金属粒子では, $\mathrm{Pd} /(\mathrm{Pt}+\mathrm{Pd})$ モ ル比 $=0.15$ の粒子の場合, 表面の $43.5 \%$ が Pdで覆われ, $\mathrm{Pd} /(\mathrm{Pt}+\mathrm{Pd})$ モル比 $=0.5$ の粒子で $89.0 \%$ が $\mathrm{Pd}$ で覆われる。同 様な結論は Deng ら ${ }^{13)}$ も報告しており, 彼らは表面での Pdの 偏析および第二層付近での Pt の濃縮を報告している。一方, このような計算化学的なアプローチに加え, Fiermans ら ${ }^{14)} に$ よるXPS 分析, Guillon ら ${ }^{15)}$ による LEIS (ion microprobe mass analysis）分析などによる表面分析によっても，バイメタリッ ク粒子表面での Pd の偏析は確証されている。これらの知見に 基づくと, 担体の違いによる最適 $\mathrm{Pd} /(\mathrm{Pt}+\mathrm{Pd})$ モル比の違いを 金属粒子径の違いに帰属することができる。すなわち, 本研究 で調製した $\mathrm{Pt}-\mathrm{Pd} / \mathrm{Al}_{2} \mathrm{O}_{3}, \mathrm{Pt}-\mathrm{Pd} / \mathrm{TiO}_{2}$ 触媒の金属分散度は，それ
ぞれ 65～83\%，18～24\% であった。 $\mathrm{Pt}-\mathrm{Pd} / \mathrm{TiO}_{2}$ 触媒では明ら かに金属粒子径が大きく, 金属粒子表面を少量の Pd で被覆す ることが可能である。つまり, 耐硫黄性の高い Pd が表面に露 出することで硫黄存在下での触媒活性が向上したと考えられ る。この結論は Yasuda ら ${ }^{5)}$ が報告している Pt-Pd/USY 触媒 （最適 $\mathrm{Pd} /(\mathrm{Pt}+\mathrm{Pd})$ モル比 $=0.8 ）$ の金属分散性が $43 \sim 59 \%$ と, より小さな金属粒子が形成されていることからも支持される。

\section{2. Pt と Pd の複合化による活性向上因子}

種々の担体上 $\left(\mathrm{Al}_{2} \mathrm{O}_{3}, \mathrm{SiO}_{2}-\mathrm{Al}_{2} \mathrm{O}_{3}, \mathrm{~B}_{2} \mathrm{O}_{3}-\mathrm{Al}_{2} \mathrm{O}_{3}\right.$, USY ゼオ ライト等) での Pt と Pd の複合化は, 硫黄成分存在下での触媒 活性を大幅に向上させることが知られている bayashi ら ${ }^{17)}$ は Pt-Pd/USY 触媒の EXAFS (extended X-ray absorption fine structure) 測定を行い, Pt と Pd の電子的相互作用によ り電子久損状態の $\mathrm{Pt}$ 種が生成 $\left(\mathrm{P}^{x \delta+}-x \mathrm{Pd}^{\delta-}\right)$ し, 硫化条件下で 金属相を保持するためとしている。同様な電子的相互作用を Navarro $5^{6)}$ も報告して扔り, 彼らはそのような電子密度の低 い貴金属は電子受容体（アクセプター）である硫黄との結合が 弱いことに起因すると考察している。一方, Lousset ら ${ }^{18)}$ は, Pt-Pd 合金ロットのレーザー蒸発法により調製したバイメタリ ック Pt-Pd 触媒ではそのような電子的相互作用は発現しないと 報告している。さらに, Fujikawa ${ }^{19)} ら$ は, Pt-Pd/ $/ \mathrm{SiO}_{2}-\mathrm{Al}_{2} \mathrm{O}_{3}$ 触 媒の EXAFS 測定により，その複合効果を Pt 粒子上に分散した $\mathrm{Pd}$ 種に帰属している。以上のように, Pt と Pd の複合効果につ いては, いまだ電子論的効果なのか幾何学的効果なのか明らか にされていない。

Fig. 9 では, 架橋型吸着種の吸収強度の違いにより, Pt と $\mathrm{Pd}$ のバイメタリック粒子の形成が明らかであった。さらに Fig. 11 では, Pt と Pdの複合効果を示した Pt-Pd(Pd: 0.8) $/ \mathrm{Al}_{2} \mathrm{O}_{3}$ 触媒上に吸着した $\mathrm{CO}$ の赤外吸収スペクトルにより, Pt と $\mathrm{Pd}$ 間での電子的相互作用は起こらないと結論した。これらの知見 に基づくと, Pt と Pdの複合効果は幾何学的効果によると推察 される。すなわち, Pt 触媒と Pd 触媒を耐硫黄性の観点から比 較すると, Pd触媒がより有効であった。さらに, 最適 $\mathrm{Pd} /(\mathrm{Pt}+$ Pd) モル比の違いは, 金属粒子径の違いに帰属され, 表面での $\mathrm{Pd}$ の偏析が起こることより説明された。つまり, Pt と Pdの複

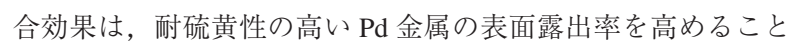
に起因すると考えられる。

\section{5. 結 言}

$\mathrm{TiO}_{2}, \mathrm{Al}_{2} \mathrm{O}_{3}$ 担持 $\mathrm{Pt}-\mathrm{Pd}$ バイメタリック触媒による硫黄成分 
存在下でのナフタレン水素化反応を行った。それぞれの担体上 での Pt と Pdの複合化により大幅な触媒活性の向上が見られ た。最適 $\mathrm{Pd} /(\mathrm{Pt}+\mathrm{Pd})$ モル比は, $\mathrm{TiO}_{2}$ 担持触媒では $0.5, \mathrm{Al}_{2} \mathrm{O}_{3}$ 担持触媒では 0.8 であった。担体の違いによる最適 $\mathrm{Pd} /(\mathrm{Pt}+\mathrm{Pd})$ モル比の違いは，金属粒子径の違いに起因する Pt-Pdバイメ夕 リック粒子表面の Pd 露出率の違いに帰属された。さらに, 触 媒上に吸着した COの赤外スペクトルにより, Pt-Pdバイメタ リック粒子の形成が確認されたが，Pt と Pd 間での電子的な相 互作用は見られなかった。よって, Pt と Pd の複合効果は幾何 学的効果によると推察した。

\section{付 記}

本研究は, 経済産業省「産油国石油精製技術等対策事業」を もって(財)国際石油交流センターが(社) 石油学会に委託した研 究事業として行われたものである。

\section{References}

1) Cooper, B. H., Donnis, B. B. L., Appl. Catal. A: General, 137, 203 (1996)

2) Fujikawa, T., Idei, K., Usui, K., Sekiyu Gakkaishi (J. Jpn. Petrol. Inst.), 42, (4), 271 (1999).

3) Fujikawa, T., Idei, T., Ebihara, T., Mizuguchi, H., Usui, K., Appl. Catal. A: General, 192, 253 (2000).

4) Pawelec, B., Mariscal, R., Navarro, R. M., Bokhorst, S. V., Rojas, S., Fierro, J. L. G., Appl. Catal. A: General, 225, 223 (2002).
5) Yasuda, H., Yoshimura, Y., Catal. Lett., 46, 43 (1997).

6) Navarro, R. M., Pawelec, B., Trejo, J. M., Mariscal, R., Fierro, J. L. G., J. Catal., 189, 184 (2000).

7) Giorgi, J. B., Schroeder, T., Bäumer, M., Freund, H.-J., Surf. Sci., 498, L71 (2002).

8) Liotta, L. F., Martin, G. A., Deganello, G., J. Catal., 164, 322 (1996).

9) Dulaurent, O., Chandes, K., Bouly, C., Bianchi, D., J. Catal., 188, 237 (1999).

10) Juszczyk, W., Karpiński, Z., Ratajczykowa, I., Stanasiuk, Z., Zieliński, J., Sheu, L.-L., Sachler, W. M. H., J. Catal., 120, 68 (1989).

11) Miura, H., Hondou, H., Sugiyama, K., Matsuda, T., Gonzalez, R. D., Proceedings of the 9th International Congress on Catalysts, 1988, p. 1307.

12) Rousset, J. L., Khanra, B. C., Cadrot, A. M., Aires, F. J. C. S., Renouprez, A. J., Pallarin, M., Surf. Sci., 352, 583 (1996).

13) Deng, H., Hu, W., Shu, X., Zhao, L., Zhang, B., Surf. Sci., 517, 177 (2002).

14) Fiermans, L., Gryse, R. D., Doncker, G. D., Jacobs, P. A., Martens, J. A., J. Catal., 193, 108 (2000).

15) Guillon, E., Lynch, J., Uzio, D., Didillon, B., Catal. Today, 65, 201 (2001).

16) Jan, C.-A., Lin, T.-B., Chang, J.-R., Ind. Eng. Chem. Res., 35, 3893 (1996)

17) Matsubayashi, N., Yasuda, H., Imamura, M., Yoshimura, Y., Catal. Today, 45, 375 (1998).

18) Rousset, J. L., Stievano, L., Aires, F. J. C. S., Geantet, C., Renouprez, A. J., Pallarin, M., J. Catal., 202, 163 (2001).

19) Fujikawa, T., Tsuji, K., Mizuguchi, H., Goto, H., Idei, K., Usui, K., Catal. Lett., 63, 27 (1999).

\section{要 旨 \\ ナフタレン水素化反応における $\mathrm{TiO}_{2}$ および $\mathrm{Al}_{2} \mathrm{O}_{3}$ 担持バイメタリック Pt-Pd 触媒の耐硫黄性}

伊藤耕輝，佐藤香織，富能忠寛，三宅昌夫，大嶋正明，黒川秀樹，杉山和夫，三浦 弘

埼玉大学工学部応用化学科, 338-8570 さいたま市桜区下大久保 255

$\mathrm{TiO}_{2}$ および $\mathrm{Al}_{2} \mathrm{O}_{3}$ 担持バイメタリック Pt-Pd 触媒によるナフ タレン水素化反応を, ジメチルジスルフィド（DMDS）を添加 した場合および添加しない場合において，0.95〜2.45 MPa， $473 \mathrm{~K}$ で行った。さらに, 吸着した CO の赤外吸収スペクトル により調製した触媒の物性評価を行った。担持 $\mathrm{Pt}$ 触媒と比較 すると，担持 Pd 触媒は硫黄化合物が存在する条件下で高い触 媒活性を示した。硫黄化合物が存在しない場合には, Pt 触媒 は Pd 触媒よりも高活性であることから，Pd触媒はより高い耐 硫黄性を有していることを示していた。

Pt と Pd を共存させると, 硫黄化合物存在下での触媒活性が
大幅に向上し, 明らかな複合効果を示した。しかしながら, 硫 黄化合物が存在しない場合, 顕著な複合効果は発現しなかっ た。さらに, $\mathrm{Pd} /(\mathrm{Pt}+\mathrm{Pd})$ モル比は, それぞれ $\mathrm{Al}_{2} \mathrm{O}_{3}$ 担持触媒 $0.8, \mathrm{TiO}_{2}$ 担持触媒で 0.5 であった。これらの最適值の違いは, 金属粒子径の影響に帰属された。バイメタリック触媒に吸着し た CO の赤外吸収スペクトルは Pt-Pdバイメタリック粒子の形 成を示した。しかしながら，Pt と Pd 間での電子的な相互作用 は見られなかった。よって, Pt と Pd の複合効果は幾何学的効 果に帰属された。 